\title{
Early effects of crop tree management on undergrowth plant diversity and soil physicochemical properties in a Pinus massoniana plantation
}

\author{
Qian Lyu ${ }^{1}$, Yi Shen ${ }^{1}$, Xianwei Li ${ }^{\text {Corresp., } 1,2}$, Gang Chen $^{1,2}$, Dehui Li ${ }^{3}$, Chuan Fan ${ }^{1,2}$ \\ ${ }^{1}$ College of Forestry, Sichuan Agricultural University, Cheng Du, China \\ 2 Key Laboratory of National Forestry and Prairie Bureau on Forest Resources Conservation and Ecological Security in the Upper Reaches of Yangtze River, \\ Sichuan Agricultural University, Cheng Du, China \\ College of Urban and Rural Planning and Construction, Mianyang Normal University, Mian Yang, China \\ Corresponding Author: Xianwei Li \\ Email address: Ixw@sicau.edu.cn
}

Background. Soil and understory vegetation are vital components of forest ecosystems. Identifying the interaction of plantation management to vegetation and soil is crucial for developing sustainable plantation ecosystem management strategies. As one of the main measures of close-to-nature management of forest plantation, few studies have paid attention to the effect of crop tree management on the soil properties and understory vegetation.

Methods. A 36-year-old Pinus massoniana plantation in Huaying city, Sichuan Province was taken as the research object to analyse the changes in undergrowth plant diversity and soil physicochemical properties under three different crop tree densities (100, 150, and $200 \mathrm{~N} / \mathrm{ha}$ ).

Results. Our results showed that the contents of available phosphorus, organic matter and hydrolysable nitrogen in the topsoil increased significantly after crop tree management, while content of available potassium decreased. The composition of shrub and herb layer was richer, and the dominant species were obviously replaced after crop tree management. The Shannon-Wiener index and Richness index of shrub layer, and the diversity of herb layer increased significantly after crop tree management. Herb layer diversity indexes and Richness index of shrub layer were closely related to soil organic matter, available phosphorus, hydrolysable nitrogen, available potassium, soil moisture and bulk density. As the main limiting factors for plant growth, nitrogen, phosphorus and potassium were closely related to plant diversity and to the distribution of the dominant species. At the initial stage of crop tree management, each treatment significantly improved the soil physicochemical properties and plant diversity of Pinus massoniana plantation, and the comprehensive evaluation was $200 \mathrm{~N} / \mathrm{ha}>100 \mathrm{~N} / \mathrm{ha}>150 \mathrm{~N} / \mathrm{ha}>\mathrm{CK}$. Compared with other treatments, $200 \mathrm{~N} /$ ha had the best effect on improving the undergrowth environment of the Pinus massoniana plantation in the initial stage of crop tree management. 
1 Early effects of crop tree management on undergrowth plant diversity and soil

2 physicochemical properties in a Pinus massoniana Lamb. plantation

3 Qian Lyu ${ }^{1}$, Yi Shen ${ }^{1}$, Xianwei Li ${ }^{1,2}$, Gang Chen ${ }^{1,2}$, Dehui Li ${ }^{3}$, Chuan Fan ${ }^{1,2}$

4

$5{ }^{1}$ College of Forestry, Sichuan Agricultural University, Chengdu, China

$6 \quad{ }^{2}$ Key Laboratory of National Forestry and Prairie Bureau on Forest Resources Conservation and

7 Ecological Security in the Upper Reaches of Yangtze River (Sichuan Agricultural University),

8 Chengdu, China

$9{ }^{3}$ College of Urban and Rural Planning and Construction, Mianyang Normal University,

10 Mianyang 621000, China

11 Corresponding Author: Xianwei $\mathrm{Li}^{1,2}$

12 Sichuan Agricultural University, Huimin Road 211, 611130 China.

13 Email address: E-mail address: 1xw@sicau.edu.cn

14 


\section{Abstract}

16 Background. Soil and understory vegetation are vital components of forest ecosystems.

17 Identifying the interaction of plantation management to vegetation and soil is crucial for

18 developing sustainable plantation ecosystem management strategies. As one of the main

19 measures of close-to-nature management of forest plantation, few studies have paid attention to

20 the effect of crop tree management on the soil properties and understory vegetation.

21 Methods. A 36-year-old Pinus massoniana plantation in Huaying city, Sichuan Province was

22 taken as the research object to analyse the changes in undergrowth plant diversity and soil

23 physicochemical properties under three different crop tree densities (100, 150, and $200 \mathrm{~N} / \mathrm{ha})$.

24 Results. Our results showed that the contents of available phosphorus, organic matter and

25 hydrolysable nitrogen in the topsoil increased significantly after crop tree management, while

26 content of available potassium decreased. The composition of shrub and herb layer was richer,

27 and the dominant species were obviously replaced after crop tree management. The Shannon-

28 Wiener index and Richness index of shrub layer, and the diversity of herb layer increased

29 significantly after crop tree management. Herb layer diversity indexes and Richness index of

30 shrub layer were closely related to soil organic matter, available phosphorus, hydrolysable

31 nitrogen, available potassium, soil moisture and bulk density. As the main limiting factors for

32 plant growth, nitrogen, phosphorus and potassium were closely related to plant diversity and to

33 the distribution of the dominant species. At the initial stage of crop tree management, each 
34 treatment significantly improved the soil physicochemical properties and plant diversity of Pinus

35 massoniana plantation, and the comprehensive evaluation was $200 \mathrm{~N} / \mathrm{ha}>100 \mathrm{~N} / \mathrm{ha}>150 \mathrm{~N} / \mathrm{ha}>$

36 CK. Compared with other treatments, $200 \mathrm{~N} /$ ha had the best effect on improving the undergrowth

37 environment of the Pinus massoniana plantation in the initial stage of crop tree management.

38 Keywords

39 Crop trees, Soil physicochemical properties, Dominant species, Plant diversity

\section{Abbreviations}

41 SOM: Soil Organic matter

42 AP: Available potassium

43 AN: Hydrolysable nitrogen

$44 \quad$ AK: Available potassium

$45 \quad$ SM: Soil moisture

46 BD: Bulk density

\section{Introduction}

Forest plantations are an important component of global forest resources, and their

49 construction has greatly increased global forest coverage and solved the conflict between the

50 supply of and demand for wood (Payn et al., 2015). However, for a long time, forest plantations 
51 have grown only one tree species and have lacked scientific management techniques, resulting in

52 ecological problems that are harmful to forest health, such as decreased plant diversity (Paillet et

53 al., 2010), declining soil fertility, and frequent occurrences of diseases and insect pests (Li et al.,

54 2020a). How to solve these problems and take into account the ecological and economic benefits

55 of plantations is the focus of the current whole-plantation management strategies. According to

56 the results of the eighth forest resources census in China, forested areas of China is 208 million

57 ha, forest coverage rate is $21.63 \%$, and forest plantation area is 69 million ha, which accounts for

$5836 \%$ of the national forest area (Shen et al., 2019). The forest plantation area in China accounts

59 for approximately $33 \%$ of the world's total forest plantation area, ranking first in the world, and

60 China is also the country with the fastest growth rate for forest plantations (Liu et al., 2021; Su et

61 al., 2021). Chinese plantations have some problems, such as weakening carbon sequestration

62 functions, inappropriate ecosystem structures, low productivity, and weak ecological functions

63 and stability (Pan et al., 2018). Therefore, in order to improve the current situation of plantation,

64 it is particularly important to adjust the forest plant composition and site conditions to a healthy

65 succession process through rational forest management.

66 Many studies have shown that plantation management mainly changes stand density

67 through thinning to influence light heterogeneity and stand space for undergrowth plants (Yang

68 et al., 2018; Ali et al., 2019). The thinning intensity in boreal ecosystems is coordinated with

69 plant diversity. Species diversity varies among different soil types, and protecting biodiversity

70 requires a wide range of soil types (Kershaw et al., 2015). German close-to-nature forestry 
71 theory has achieved good results in experimental studies of various plantation forests (Ward,

72 2017). However, research on close-to-nature forest plantation management in China is still in its

73 infancy. Crop tree management is one of the forest management methods used in close-to-nature

74 management, and research on crop tree management in China and worldwide is mostly aimed at

75 individual tree growth and stand growth (Miller, 2000; Ray et al., 2011; Ward, 2017). It is rare to

76 study the effects of crop tree management on the function of plantation ecosystems or to reveal

77 the mechanisms of the effects of crop tree management on plant community structure and the

78 soil physical and chemical properties under succession. Crop tree management can be regarded

79 as a particular kind of tending that involves thinning with a few dominant crop trees as the

80 management centre (Perkey 1994). Different selective cutting methods are used to cut down the

81 disturbance trees that affect the growth of the crop trees, and it is beneficial to form gaps for the

82 renewal of natural species and the accelerated growth of young trees under the forest canopy

83 (Chen et al., 2019).

84 Understory plants are important components of forests because they are responsible for the

85 majority of the vascular plant diversity of forest ecosystems (Yilmaz, Yilmaz \& Akyuz, 2018).

86 Undergrowth plant diversity can be used as an indicator of biodiversity to indicate the renewal

87 and development of the ecosystem (Barbier, Gosselin \& Balandier, 2008). Soil is required for the

88 survival of forest trees and predicts changes in ecosystem multifunctionality (Lucasborja \&

89 Delgadobaquerizo, 2019). Soil quality conditions can interact with plant diversity; soil

90 physicochemical properties indirectly affect plant species composition by influencing presence 
91 of soil mycorrhizal community and soil microorganisms (Perezramos et al., 2008). Plant

92 diversity affects soil fertility for a long time, and an increase in soil total nitrogen may lead to the

93 release of nitrogen limitation on certain species, thus increasing the number of plant species

94 (Lopezangulo et al., 2020). Soil pH significantly affect plant species richness and change

95 distribution range of plants due to larger species pools in high-pH soils (Crespomendes et al.,

96 2019). Relatively wet and basic soils lead to high understory cover and diversity (Kooijman et

97 al., 2019). Soil physicochemical properties are closely related to plant diversity. Therefore,

98 appropriate forest management is needed to guide the ecological restoration of forest plantations

99 to promote the development of undergrowth vegetation and improve forest productivity (Goded

100 et al., 2019; Yao et al., 2019), which improve the ecological and physiological environment of

101 the stand and have an impact on the diversity of plants under the forest (Zhou et al., 2016).

102 Pinus massoniana, one of the most important tree species in southern China, has been

103 widely planted in this ecologically and environmentally vulnerable area because of its high

104 adaptability to drought and barren soils and its capacity to retain water and nutrients (Ma et al.,

105 2014). Pinus massoniana plantations cover approximately 10 million ha and account for

106 approximately $20 \%$ of the planted forests in southern China (Yu et al., 2019). An appropriate

107 forest quality improvement plan is an urgent scientific and technological need for securing the

108 ecological restoration achievements in low mountainous areas of eastern Sichuan. Crop tree

109 management can be used to scientifically manage and transform Pinus massoniana plantations; it

110 can not only meet human demand for wood but also improve plant community structure, increase 
111 the diversity of plants in the forest understory and simultaneously allow the various benefits of

112 the plantation to develop fully. In this study, taking a Pinus massoniana plantation as the

113 research object, different crop tree density treatments were used to explore the effects of crop

114 tree management on plant diversity and soil physicochemical properties. The goals of this study

115 are to identify the optimal crop tree density for the natural restoration of local plantations and to

116 provide a reference for the selection and study of management practices for Pinus massoniana

117 plantations.

\section{Materials \& methods}

\section{Study site}

120 The study area is located at Tianchi Forest Farm, Hua Ying city, Sichuan Province, in the

121 low mountainous area of eastern Sichuan. The area is subtropical and in the middle of a humid

122 monsoon climate region (106 $47^{\prime} 30^{\prime} \mathrm{E}$, 30²0’29’N, Fig. 1). The climate is mild, with uneven

123 rainfall and large temperature differences. The multiyear average temperature in Huaying is 17.2

$124{ }^{\circ} \mathrm{C}$. The rainfall is abundant; the highest annual average rainfall is $1441.7 \mathrm{~mm}$, the lowest annual

125 average rainfall is $854.9 \mathrm{~mm}$, and the multiyear average rainfall is $1087.84 \mathrm{~mm}$. Soil is typical

126 yellow soil with poor tillage and low fertility. Pinus massoniana plantation was established in

127 1982. Although necessary management measures have been performed in the stands, the overall

128 management level has been low. In the crop tree plot of Pinus massoniana plantation, due to the 
129 ground is covered with a large number of Pinus massoniana needles, plant diversity under the

130 forest canopy is poor. Shrubs are mainly Litsea pungens Hemsl, Mallotus barbatus (Wall.) and

131 Quercus serrata Thunb, and the herbaceous layer is mainly covered with ferns.

\section{Experimental design and sampling}

133 In January 2015, site conditions were basically same throughout the study area according to

134 the principle of typical sampling. The 33-year-old near-mature forest stand that had the same

135 forest age and management history was managed as crop trees, but few management measures

136 were taken before this study. Three crop tree densities $(100,150$, and $200 \mathrm{~N} / \mathrm{ha}$, marked as A, B,

137 and C, respectively) were established. A designated sample plot without crop tree management

138 was also established as the control plot $(\mathrm{CK})$. Three $30 \mathrm{~m} \times 30 \mathrm{~m}$ sample squares were set up in

139 Pinus massoniana plantation with different management modes. There were 12 sample plots in

140 total. Trees with vigorous growth, straight trunks, well-developed crowns, and no damage,

141 diseases or insect pests that were located in the main forest layer were selected as the crop trees

142 and were permanently labelled with red flagging tapes. At the same time, any competitive trees

143 that affected the growth of the crop tree were identified to prevent them from touching the crop

144 tree. An overview of a crop tree sample plot is shown in Table 1. In the crop tree management

145 sample plot, the general trees (non-crop trees) were marked with flagging tapes and the boundary

146 trees were marked with yellow flagging tapes. Protective fences were established around the

147 sample plots (Fig. 2).

Peer) reviewing PDF | (2021:03:58821:1:0:NEW 3 Jun 2021) 
148 Undergrowth species survey

149 Undergrowth plants in the sample plots were surveyed in October 2018 . Five $5 \mathrm{~m} \times 5 \mathrm{~m}$

150 quadrats were established shrub survey in the four corners of each treatment and in the centre of

151 each of the sample plots in Pinus massoniana plantation. Then, ten $1 \mathrm{~m} \times 1 \mathrm{~m}$ quadrats were

152 randomly established for the herbaceous survey in the sample plots. The species name, number

153 of plants, height, coverage, crown width and other data for each plant in the shrub and herb

154 sample quadrats were recorded. According to the data obtained from the sample plot survey, the

155 importance values of the plants in the sample plots were calculated, and then the diversity index

156 was calculated. The species diversity indicators included the species importance value (IV),

157 richness index (R), species number (S), Simpson index (D), Shannon-Wiener index (H), and

158 Pielou index (J) (Wang et al., 2019). The formulas are as follows:

159 Important value (\%): $I V=($ Relative density + Relative frequency + Relative coverage $) / 3$

$160 \quad(1)$

$161 \mathrm{R}=\mathrm{S}$

162 Simpson index: $D=1-\sum_{\mathrm{i}=1}^{\mathrm{S}} \mathrm{P}_{\mathrm{i}}^{2}$

163 Shannon-Wiener index: $H=-\sum_{\mathrm{i}=1}^{\mathrm{S}} \mathrm{P}_{\mathrm{i}} \ln P_{i}$

164 Pielou index: $J=\mathrm{H} / \ln \mathrm{S}$

165 Note: "S", total number of species in the sample plot; "P $\mathrm{P}_{\mathrm{i}}$ ", the proportion of the number of

166 individuals of one species to the sum of the number of individuals of all species in this layer 
167 (Alatalo, 1981).

168 Niche breadth was calculated based on the Shannon-Wiener niche breadth index (Yadav et

169 al., 2015):

$170 \quad \mathrm{~B}_{\mathrm{i}}=-\sum_{j=1}^{r} P_{i j} \ln P_{i j}$

171 Note: " $\mathrm{B}_{\mathrm{i}}$ ", the niche breadth of species " $\mathrm{i}$ "; $\mathrm{P}_{\mathrm{ij}}=\mathrm{n}_{\mathrm{ij}} / \mathrm{N}_{\mathrm{i}}$, " $\mathrm{n}_{\mathrm{ij}}$ ", the importance value of species

172 "I" for resource " $\mathrm{j}$ "; " $\mathrm{N}_{\mathrm{i}}$ ", the sum of the importance values of species "i" for all resources. The

173 importance value of " $\mathrm{P}_{\mathrm{ij}}$ " represents species "i" for resource " $\mathrm{j}$ ” and accounts for the proportion

174 of the importance value of this species for all resources; "r", the total number of resource units;

175 “j”, the different transformation modes (Tonkin, Arimoro \& Haase, 2016).

176 Soil investigation

177 A soil drill (5 $\mathrm{cm}$ in diameter) was used in each crop tree management stand to randomly

178 arrange five sampling points in an "S" shape to collect soil samples. Soil samples at depths of

$1790 \sim 10 \mathrm{~cm}$ and 10 20 cm were collected separately at each sampling point and mixed evenly.

180 Approximately $1.5 \mathrm{~kg}$ of each sample was selected according to the quartet method, packed into

181 plastic bags and taken back to the laboratory within $24 \mathrm{~h}$. Fine roots, fine gravel and litter were

182 separated from the soil manually. Then, the soil samples were air-dried and passed through $2 \mathrm{~mm}$

183 and $0.149 \mathrm{~mm}$ sieves. A subsample was dried at $105^{\circ} \mathrm{C}$ for $48 \mathrm{~h}$ to constant weight to measure

184 the soil gravimetric moisture content and soil bulk density (Luo et al., 2018). The organic matter

185 content of the soil was determined by hydration with the potassium dichromate oxidation- 
186 colorimetric method (Yang et al., 2020). The soil $\mathrm{pH}$ was measured in a 1:2.5 water and soil

187 mixture whisked together for 10 min with a glass rod, followed by standing for $1 \mathrm{~h}$ and then

188 being measured with an electronic $\mathrm{pH}$ metre (Li et al., 2020a). Soil hydrolysable nitrogen was

189 measured by the alkali-hydrolysed diffusion absorption method (Chen et al., 2010). Available

190 potassium was measured by the ammonium acetate extraction-flame photometric detection

191 method (Rich, 1958). Soil available phosphorus was measured by extracting subsamples with

$1920.03 \mathrm{M} \mathrm{NH} 4 \mathrm{~F}-0.025 \mathrm{M} \mathrm{HCl}$ (Mariotte et al., 2020).

\section{Statistical analyses}

194 In this study, Excel 2010 was used for data processing, origin Pro 8.0 was used to create the

195 figures, and SPSS 20.0 was used for statistical analysis. Single factor analysis of variance (one-

196 way ANOVA) and multiple comparisons (LSD) were used to test the soil index and plant

197 diversity index in the Pinus massoniana forest under the different treatments. Two-way ANOVA

198 was used to test whether there was a significant interaction among the different crop tree

199 treatments, different soil layers and soil physicochemical properties. Pearson correlation analysis

200 was carried out between the plant diversity index and the soil physicochemical properties. The

201 principal component variables were extracted from the comprehensive indexes of soil

202 physicochemical properties and plant diversity by principal component analysis (PCA), a

203 comprehensive evaluation value was calculated through the comprehensive evaluation model.

204 Pearson correlation analysis and principal component analysis (PCA) was performed using the 
205 OmicShare tools, a free online platform for data analysis (http://www.omicshare.com/tools). An

206 RDA of the environmental factors and dominant species was performed with CANOCO 5.0.

$$
F=F 1 \times \frac{\lambda 1}{\lambda 1+\lambda 2+\lambda 3}+F 2 \times \frac{\lambda 2}{\lambda 1+\lambda 2+\lambda 3}+F 3 \times \frac{\lambda 3}{\lambda 1+\lambda 2+\lambda 3}
$$

In the formula, F1, F2 and F3 are the main components, $\lambda 1, \lambda 2$ and $\lambda 3$ are the characteristic root values, and $\mathrm{F}$ is the comprehensive evaluation value.

\section{Results}

\section{Plant composition and undergrowth plant diversity in the initial stage of crop tree}

\section{2 management}

214 the control treatment (Table 2). In terms of shrub layer, $\mathrm{C}$ treatment has the largest number of

215 species among all treatments. The dominant species under the three crop tree treatments changed

216 compared with those under the control treatment. The dominant species in the control treatment

217 were Cinnamomum camphora (Linn.), Debregeasia orientalis, Litsea pungens, Mallotus

218 barbatus, Quercus serrata and Urena lobata (Linn.). The dominant species in the A treatment

219 were Cinnamomum camphora, Eurya brevistyla Kobuski, Litsea pungens, Mallotus barbatus and

220 Quercus serrata. The dominant species in the B treatment were Litsea pungens, Mallotus

221 barbatus, Myrsine africana (Linn.) and Quercus serrata. The dominant species in the C

222 treatment were Litsea pungens, Mallotus barbatus, Melastoma malabathricum Linnaeus and

223 Rubus pirifolius (Table 2). 
225 (Table 3). The proportion of pteridophytes in the control was relatively high, but with the

226 increase in the intensity of the different treatments, the proportion of pteridophytas gradually

227 decreased, which promoted the emergence of more different herbaceous species. The dominant

228 species under the three crop tree treatments changed compared with those under the control

229 treatment. The dominant species in the control treatment were Dryopteris fuscipes C. Chr,

230 Miscanthus sinensis, Iris tectorum Anderss, and Setaria plicata (Lam.). The dominant species in

231 the A treatment were Dicranopteris dichotoma (Thunb.), Iris tectorum and Setaria plicata. The

232 dominant species in the B treatment were Dryopteris fuscipes, Microlepia hancei Prantl,

233 Miscanthus sinensis and Setaria plicata. The dominant species in the C treatment were

234 Microlepia hancei, Miscanthus sinensis, Dicranopteris dichotoma and Stenoloma chusanum

235 Ching (Table 3).

236 In the shrub layer, crop tree management on Pinus massoniana plantation had a significant

237 effect on the Pielou index, Richness index, and Shannon-Wiener index $(p<0.05)$, but had no

238 significant effect on the Simpson index (Fig. 3). Compared to the control, the Richness index of

239 crop tree management increasing by $61.54 \%, 61.54 \%$ and $107.69 \%$ for treatments $\mathrm{A}, \mathrm{B}$ and C,

240 respectively, and the Shannon-Wiener index of crop tree management increasing by $21.17 \%$,

$24121.20 \%$ and $23.27 \%$, for treatments A, B and C, respectively. The Shannon-Wiener index and

242 Richness index of the shrub layer were the highest in the $\mathrm{C}$ treatment. In the herb layer, the

243 Pielou index, Richness index, Shannon-Wiener index and Simpson index of the herb layer were 
244 significantly higher than those of the control $(p<0.05)$ (Fig. 3). The Pielou index and Simpson

245 index of herb layer were $\mathrm{C}>\mathrm{A}>\mathrm{B}>\mathrm{CK}$. The Richness index of crop tree management was

2461.17 to 1.25 times higher than control. Compared to the control, The Shannon-Wiener index of

247 crop tree management, increasing by $15.90 \%, 10.63 \%$ and $15.82 \%$, for treatments $\mathrm{A}, \mathrm{B}$ and $\mathrm{C}$,

248 respectively.

249 Effects of crop tree management on soil physicochemical properties

250 Table 4 shows that the effect of crop tree management on the physicochemical properties of

251 topsoil in Pinus massoniana plantation is significantly stronger than that on deep soil properties.

252 In the $0 \sim 10 \mathrm{~cm}$ soil layer, compared with those under $\mathrm{CK}$, the contents of soil organic matter and

253 available phosphorus increased significantly $(p<0.05)$, while soil available potassium and soil

254 bulk density decreased significantly $(p<0.05)$. Under treatments A and C, the content of soil

255 hydrolysable nitrogen was significantly higher than under CK $(p<0.05)$; however, that under

256 treatment B was significantly lower than that under CK $(p<0.05)$. In the $10 \sim 20 \mathrm{~cm}$ soil layer,

257 the treatments had no significant effect on soil $\mathrm{pH}$, organic matter, soil moisture or soil bulk

258 density, but the contents of available phosphorus and hydrolysable nitrogen in soil increased

259 significantly compared with those under CK $(p<0.05)$.

260 Except for the index of $\mathrm{pH}$, crop tree management had significant effect on other soil

261 properties (Table 5, $p<0.05$ ). Only soil available potassium, soil moisture and soil bulk density

262 were significantly affected by different soil layers (Table 5, $p<0.05$ ). The interactions of crop 
263 tree management and the different soil layers had significant effects on soil hydrolysable

264 nitrogen and soil bulk density (Table $5, p<0.05$ ).

\section{Relationships between plant characteristics and soil factors}

As seen in Fig. 4, the correlation coefficient between herb layer plant diversity index and

soil properties was higher than that between shrub layer plant diversity and soil properties. There was no correlation between D1 and soil physical or chemical properties. H1 was significantly positively correlated with SP $(P<0.01)$, while significantly negatively correlated with AK $(P<$ AK and $\mathrm{BD}(P<0.05)$. R1 was significantly positively correlated with SOM, AP, AN and SM, but significantly negatively correlated with $\mathrm{BD}$ and $\mathrm{AK}(P<0.05)$. D2 had highly significant positive correlation with SM and SP $(P<0.01)$, but significantly negatively correlation with AK and $\mathrm{BD}(\mathrm{P}<0.01)$. There was a positive correlation between $\mathrm{D} 2$ and $\mathrm{SM}(P<0.05)$. $\mathrm{H} 2$ was with SK, SM or BD $(P<0.01)$. J2 was highly significantly positively correlated with SOM and AN $(P<0.01)$, while highly negatively correlated with AK and BD $(P<0.01)$. S2 was highly significantly positively correlated with $\operatorname{SOM}(P<0.01)$, while highly negatively correlated with $\mathrm{AK}$ and $\mathrm{BD}(P<0.01)$. 
282 better reflect the relationship between shrub layer species and environmental factors, in which

283 AK had a very significant effect on shrub layer species $(p<0.01)$. Figure 5B showed the RDA

284 analysis of shrub layer under $10 \sim 20 \mathrm{~cm}$ soil layer. At this level, RDA1 explained $54.42 \%$ of all

285 information. RDA2 explained $21.84 \%$ of all information. The total degree of explanation of the

286 two was $76.26 \%$. It reflected the actual situation of shrub layer species and environmental

287 factors, in which AK had a very significant impact on shrub layer species $(p<0.01)$, and AN had

288 a significant impact on shrub layer species $(p<0.05)$. Figure 5C showed that the total

289 explanation of the soil physical and chemical properties of the $0 \sim 10 \mathrm{~cm}$ soil layer to the herb

290 layer species was up to 70.05\%. AK, AN and AP all had significant effects on the herb layer

291 species $(p<0.01)$. Figure 5D showed the RDA analysis of herb layer under $10 \sim 20 \mathrm{~cm}$. At this

292 level, RDA1 explained 52.44\% of all information. RDA2 explained $21.52 \%$ of all information.

293 The total degree of explanation of the two was $73.96 \%$. It reflected the actual situation of herb

294 layer species and environmental factors, in which AN had a very significant impact on shrub

295 layer species $(p<0.01)$.

296 A total of 15 indexes of plant diversity and surface soil physicochemical properties under

297 crop tree management on Pinus massoniana plantation were analysed by principal component

298 analysis. As shown in Table 6, three principal component variables were extracted, and the

299 cumulative contribution rate reached 89.67\% (Table 6). Therefore, the comprehensive index of

300 the three extracted principal components can be used to summarize and represent the 15

301 individual indicators. According to the comprehensive evaluation of the principal components, 
302 the close-to-nature management effects of the three crop tree treatment plots was significantly

303 higher than that in the control plots(Fig. 6), and of all the treatments, treatment $\mathrm{C}$ had the most

304 significant effect on the ecosystem service functions of Pinus massoniana plantation (Table 7).

305 Discussion

306 Effects of the early stage of crop tree management on undergrowth plant diversity and soil

307 physicochemical properties

308 The composition and structure of the forest community have strong influences on the forest

309 ecosystem (Ding et al., 2017). Increasing plant diversity is increasingly regarded as the most

310 effective means of improving the ecosystem functions of forest plantations, and plants with

311 various life forms can better maintain the stability of forest ecosystems. In the context of climate

312 warming and the increasing demand for wood products, there must be a better understanding of

313 the proper management of biodiversity and ecosystem functions (Schulze et al., 2016). The plant

314 composition and diversity under the three different crop tree densities were more abundant than

315 that in the control treatment, which may be due to the fact that the thinning of disturbed trees can

316 improve the light conditions in the stand by reducing the stand density and canopy density,

317 increasing the vegetative area and growth space of plants, promoting the growth and

318 development of shrubs and herbs under the forest, and making the composition and site

319 conditions of forest vegetation develop in a healthy succession direction(Romeo et al., 2020;

320 Sanaei et al., 2021). And most studies have found that the increase in plant diversity were related 
321 to light and hydrothermal conditions in forests, thereby directly or indirectly affected the

322 characteristics of aboveground and underground forests (Deng et al., 2020; Aun et al., 2021;

323 Gong et al., 2021). The crop tree management was also beneficial to optimize the species

324 composition of the stand. The $\mathrm{C}$ treatment had the most plant species, and the plant pattern

325 showed a transition from light-requiring plants to light-neutral plants and then to shade plants.

326 The niche breadth of the light-loving plants such as Cinnamomum camphora (Linn.), Quercus

327 serrata Thunb and Urena lobate (Linn.) was narrow. Debregeasia orientalis, a neutral plant,

328 appeared in treatment C. A shade-loving plant, L. pungens, became more common in treatment C

329 than in the other treatments. Niche breadth is a measure of the utilization of environmental

330 resources by a population and can express the status and role of the population in the community.

331 In this study, the niche breadth indicated that species and plant characteristics were more

332 abundant under $\mathrm{C}$ treatment. Generally, after crop tree management on the plantation, due to the

333 removal of large plants, larger canopy gaps exist, and the sufficient light is more conducive to

334 the growth of light-loving plants (Haughian \& Frego, 2016), both in space and time, and this

335 may induce changes in abiotic factors (light, temperature and water) and biotic factors (bacteria

336 and fungi) (Lin, Zheng \& Zheng, 2020). However, our finding is contrary to those of other

337 studies (Schulze et al., 2016; Zhou et al., 2017), perhaps because the density of the crop trees in

338 the $\mathrm{C}$ treatment was the highest. Although the light intensity in the forest increased to a certain

339 extent under treatment $\mathrm{C}$, compared with the other treatments, the forest was dark and moist,

340 resulting in a transitional environment for the plant pattern. If the operating life of the crop tree 
341 increased, it would change this pattern, and the whole woodland ecosystem would tend to be

342 stable. The heterogeneity of light conditions and canopy structure, the maintenance of tree

343 species richness and the continuity of forest are the key factors affecting the diversity of forest

344 herbaceous plants (Marialigeti et al., 2016), so the increase in the herb layer plant diversity index

345 was small in treatment $\mathrm{C}$.

346 Our results confirmed that crop tree management would increase the undergrowth plant

347 diversity, significantly increase the nutrient elements in the topsoil, and optimize the forest

348 environment, which is consistent with the results of most studies (Lindgren \& Sullivan, 2013;

349 Zhou et al., 2016). In the initial stage of crop tree management, human disturbance has a great

350 influence. Through the transportation and migration of fallen trees in the forest, the soil surface

351 layer is seriously affected, and the structure and function of soil aggregates are changed (Du et

352 al., 2020; Teramage et al., 2020). At the same time, the rapid decrease in the litter layer leads to a

353 decrease in soil water storage and absorption and affects the mechanism of the soil cycle

354 (Capowiez et al., 2021), so the soil bulk density of topsoil decreases significantly. The significant

355 increase in soil moisture may be due to the decrease in water evaporation after tree thinning and

356 the increase in precipitation in the canopy gap (Bassett, Landis \& Brudvig, 2020). In our study,

357 we found that the content of soil available potassium decreased significantly in the initial stage

358 of crop tree management. This may have been due to the increase in light intensity after thinning

359 around the crop tree increasing the demand for available potassium for plant growth, which

360 would decrease the available potassium in the soil accordingly (Wang et al., 2013). In addition, 
361 available potassium often exists in the soil in the form of potassium ions, and ion exchange

362 easily occurs, which also reduces the content of available potassium. Previous studies have

363 shown that the initial stage of crop tree management does not have a significant impact on deep

364 soil nutrients, and the results may be related to the operating life of crop trees.

365 Interaction between plants and soil

366 After crop tree management, the diversity of herb layer increased significantly, probably

367 because the herb layer plants are more sensitive than the shrub layer, most of them were annual

368 plants, and the seeds are easy to reproduce (Graf et al., 2019; Durak \& Durak, 2021). Plant

369 diversity is an important factor that affects the soil food chain and soil functions (Li et al.,

370 2020b). The content of nitrogen and phosphorus in soil is generally the limiting factor for plant

371 growth (Lucasborja \& Delgadobaquerizo, 2019), which is well confirmed in this study. On the

372 one hand, available phosphorus has a very significant positive correlation with the diversity of

373 the shrub and herb layers. The respiration of fine roots and the absorption of nutrients vary

374 among plant species, which promotes changes in the soil organism community and strengthens

375 the decomposition of litter. Large amounts of phosphorus enter the soil (Yang, Maron \&

376 Callaway, 2015). Hydrolysable nitrogen was only significantly positively correlated with the

377 Pielou index of the herb layer. Pinus massoniana has a developed root system, the shrub and

378 herb layers have high species richness, and the intertwining of roots leads to an increase in soil

379 microbial activity and quantity. Pinus massoniana fine root biomass increased significantly in 
380 the early stage of crop tree management, which strengthened the soil nitrogen cycle (Li et al.,

381 2020a). On the other hand, as the main environmental factors, the contents of soil hydrolysable

382 nitrogen, available phosphorus and available potassium significantly affected the distribution of

383 dominant species in the shrub and herb layers.

384 In the initial stage of crop tree management, the ecological environment of Pinus

385 massoniana plantation was significantly improved, the number of different plant types was

386 higher, and the natural plant regeneration was promoted. The $\mathrm{C}$ treatment had the most obvious

387 effect on the increase in topsoil nutrients in Pinus massoniana plantation, and the strong effect of

388 the plant seed bank in the forest was the most obvious. In this study, we observed that treatment

389 C was significantly more effective than treatments A and B in the improvement of plant

390 community composition and soil fertility. The forest ecosystem tended to develop towards

391 becoming closer to a natural state, which further promoted seed germination and reproduction in

392 various plants. The reason for this result is that, compared with treatments $\mathrm{A}$ and $\mathrm{B}$, treatment $\mathrm{C}$

393 retained more crop trees and required the removal of more interfering trees affecting crop tree

394 growth; therefore, treatment $\mathrm{C}$ increased the resources and space available for plant habitat more

395 than the other treatments. Generally, ecosystems are constrained by limited habitat resources,

396 and plants can accelerate their growth and promote regeneration in more favourable habitats.

397 Some studies have shown that cutting can promote plant growth and regeneration because of the

398 increase in light availability after cutting (Yang et al., 2018). In the initial stage of crop tree

399 management, the reduction in canopy density generates the most obvious changes in the forest 
400 environment in artificial forests, including more available light, increased precipitation and

401 relatively increased growth space (Chen et al., 2019).

\section{Conclusion}

The results showed that crop tree management in Pinus massoniana plantation with three

404 different crop tree densities significantly increased the plant diversity of the forest understory

405 and improved the physicochemical properties of the topsoil. The comprehensive evaluation was

$406200 \mathrm{~N} / \mathrm{ha}>100 \mathrm{~N} / \mathrm{ha}>150 \mathrm{~N} / \mathrm{ha}>\mathrm{CK}$. A crop tree density of $200 \mathrm{~N} /$ ha was the most appropriate

407 density for the initial stage of plantation crop tree management, which not only increased the

408 undergrowth plant diversity, but also promoted the interaction between vegetation and soil. The

409 crop tree density of $100 \mathrm{~N} /$ ha and $150 \mathrm{~N} /$ ha were not as effective as $200 \mathrm{~N} / \mathrm{ha}$, probably because

410 of its small number of reserved trees, canopy gaps and light intensity that could not make plants

411 grow stably in a short time. Our research provided a stronger theoretical and scientific basis for

412 the reconstruction and management of Pinus massoniana plantations. To achieve the sustainable

413 development of Pinus massoniana plantations and the accurate improvement of forest quality, it

414 is necessary to continue this study as a long-term investigation.

\section{Acknowledgements}

416 We thank Tianchi Forest Farm in Huaying city for various forms of assistance, and we

417 sincerely thank the forestry workers and instructors who worked hard for this experiment. 


\section{Funding}

419 This study was funded by a Pillar Project of the "13th" Five-Year Plan for China (grant

420 number 2017YFD060030205), German Government Loans for Sichuan Forestry Sustainable

421 Management (grant number G1403083) and the Study on Species Diversity of large diameter

422 Timber Forest of Pinus massoniana supported by Tianfu Ten Thousand talents Plan of Sichuan

423 Province (1922999002).

\section{Grant Disclosures}

425 The following grant information was disclosed by the authors:

426 A Pillar Project of the "13th” Five-Year Plan for China: 2017YFD060030205.

427 German Government Loans for Sichuan Forestry Sustainable Management: G1403083.

428 Study on Species Diversity of large diameter Timber Forest of Pinus massoniana supported by

429 Tianfu Ten Thousand talents Plan of Sichuan Province: 1922999002.

\section{Competing Interests}

431 The authors declare there are no competing interests.

\section{Author Contributions}

- Qian Lyu conceived and designed the experiments, performed the experiments, analyzed the data, prepared figures and/or tables, authored or reviewed drafts of the paper, and approved 
435 the final draft.

436 Yi Shen investigated the field, identified the species, reviewed drafts of the paper and $437 \quad$ approved the final draft.

438 Xianwei Li conceived and designed the experiments, reviewed drafts of the paper, and 439 approved the final draft.

440 - Gang Chen reviewed drafts of the paper, and approved the final draft.

441 - Dehui Li reviewed drafts of the paper, and approved the final draft.

442 - Chuan Fan reviewed drafts of the paper, and approved the final draft.

\section{References}

444

445

446

447

448

449

450

451

452

453

454

455

456

457

458

459

460

461

462

463

464

465

466

467

468

469

470
Alatalo R V. 1981. Problems in the measurement of evenness in ecology. Oikos 37:199204. DOI: $10.2307 / 3544465$.

Ali A, Dai D, Akhtar K, Teng M, Yan Z, Urbinacardona N, Mullerova J, Zhou Z. 2019. Response of understory vegetation, tree regeneration, and soil quality to manipulated stand density in a Pinus massoniana plantation. Global Ecology and Conservation 20. DOI: 10.1016/j.gecco.2019.e00775.

Aun K, Kukumägi M, Varik M, Becker H, Aosaar J, Uri M, Morozov G, Buht M, Uri V. 2021. Short-term effect of thinning on the carbon budget of young and middle-aged Scots pine (Pinus sylvestris L.) stands. Forest Ecology and Management 492. DOI: 10.1016/j.foreco.2021.119241.

Barbier S, Gosselin F, Balandier P. 2008. Influence of tree species on understory vegetation diversity and mechanisms involved - A critical review for temperate and boreal forests. Forest Ecology and Management 254:1-15. DOI: 10.1016/j.foreco.2007.09.038.

Bassett T, Landis DA, Brudvig LA. 2020. Effects of experimental prescribed fire and tree thinning on oak savanna understory plant communities and ecosystem structure. Forest Ecology and Management 464:118047. DOI: 10.1016/j.foreco.2020.118047.

Capowiez Y, Sammartino S, Keller T, Bottinelli N. 2021. Decreased burrowing activity of endogeic earthworms and effects on water infiltration in response to an increase in soil bulk density. Pedobiologia 85-86. DOI: 10.1016/j.pedobi.2021.150728.

Chen L, Han W, Liu D, Liu G. 2019. How forest gaps shaped plant diversity along an elevational gradient in Wolong National Nature Reserve. Journal of Geographical Sciences 29:1081-1097. DOI: 10.1007/s11442-019-1646-6.

Chen S, Peng S, Chen B, Chen D, Cheng J. 2010. Effects of fire disturbance on the soil physical and chemical properties and vegetation of Pinus massoniana forest in south subtropical area. Acta Ecologica Sinica 30:184-189. DOI: 10.1016/j.chnaes.2010.04.010. Crespomendes N, Laurent A, Bruun HH, Hauschild MZ. 2019. Relationships between plant species richness and soil $\mathrm{pH}$ at the level of biome and ecoregion in Brazil. Ecological 
Indicators 98:266-275. DOI: 10.1016/j.ecolind.2018.11.004.

Deng C, Zhang S, Lu Y, Froese RE, Xu X, Zeng J, Ming A, Liu X, Xie Y, Li Q. 2020. Thinning effects on forest evolution in Masson pine (Pinus massoniana Lamb.) conversion from pure plantations into mixed forests. Forest Ecology and Management 477:118503. DOI: 10.1016/j.foreco.2020.118503.

Ding Y, Zang R, Lu X, Huang J. 2017. The impacts of selective logging and clear-cutting on woody plant diversity after 40 years of natural recovery in a tropical montane rain forest, south China. Science of The Total Environment 579:1683-1691. DOI: 10.1016/j.scitotenv.2016.11.185.

Du C, Jing J, Shen Y, Liu H, Gao Y. 2020. Short-term grazing exclusion improved topsoil conditions and plant characteristics in degraded alpine grasslands. Ecological Indicators 108:105680. DOI: 10.1016/j.ecolind.2019.105680.

Gong C, Tan Q, Liu G, Xu M. 2021. Forest thinning increases soil carbon stocks in China. Forest Ecology and Management 482:118812. DOI: 10.1016/j.foreco.2020.118812.

Goded S, Ekroos J, Dominguez J, De Azcarate JG, Guitian JA, Smith HG. 2019. Effects of eucalyptus plantations on avian and herb species richness and composition in North-West Spain. Global Ecology and Conservation 19. DOI: 10.1016/j.gecco.2019.e00690.

Graf W, Kleinn C, Schall P, Nauss T, Detsch F, Magdon P. 2019. Analyzing the relationship between historic canopy dynamics and current plant species diversity in the herb layer of temperate forests using long-term Landsat time series. Remote Sensing of Environment 232:111305. DOI: 10.1016/j.rse.2019.111305.

Haughian SR, Frego KA. 2016. Short-term effects of three commercial thinning treatments on diversity of understory vascular plants in white spruce plantations of northern New Brunswick. Forest Ecology and Management 370:45-55. DOI: 10.1016/j.foreco.2016.03.055.

Kershaw HM, Morris DM, Fleming RL, Luckai N. 2015. Reconciling Harvest Intensity and Plant Diversity in Boreal Ecosystems: Does Intensification Influence Understory Plant Diversity? Environmental Management 56:1091-1103. DOI: 10.1007/s00267-015-0551-8. Kooijman AM, Weiler HA, Cusell C, Anders N, Meng X, Seijmonsbergen AC, Cammeraat LH. 2019. Litter quality and microtopography as key drivers to topsoil properties and understorey plant diversity in ancient broadleaved forests on decalcified marl. Science of The Total Environment 684:113-125. DOI: 10.1016/j.scitotenv.2019.05.285. Li X, Su Y, Yin H, Liu S, Chen G, Fan C, Feng M, Li X. 2020a. The Effects of Crop Tree Management on the Fine Root Traits of Pinus massoniana in Sichuan Province, China. Forests 11:351. DOI: 10.3390/f11030351.

Li J, Yang C, Zhou H, Shao X. 2020b. Responses of plant diversity and soil microorganism diversity to water and nitrogen additions in the Qinghai-Tibetan Plateau. Global Ecology and Conservation 22. DOI: 10.1016/j.gecco.2020.e01003.

Lindgren PMF, Sullivan TP. 2013. Influence of stand thinning and repeated fertilization on 
510

511

512

513

514

515

516

517

518

519

520

521

522

523

524

525

526

527

528

529

530

531

532

533

534

535

536

537

538

539

540

541

542

543

544

545

546

547

548

plant community abundance and diversity in young lodgepole pine stands: 15-year results. Forest Ecology and Management 308:17-30. DOI: 10.1016/j.foreco.2013.07.020.

Lopezangulo J, Pescador DS, Sanchez A, Luzuriaga AL, Cavieres LA, Escudero A. 2020. Impacts of climate, soil and biotic interactions on the interplay of the different facets of alpine plant diversity. Science of The Total Environment 698:133960. DOI: 10.1016/j.scitotenv.2019.133960.

Lucasborja ME, Delgadobaquerizo M. 2019. Plant diversity and soil stoichiometry regulates the changes in multifunctionality during pine temperate forest secondary succession. Science of The Total Environment 697:134204. DOI: 10.1016/j.scitotenv.2019.134204. Liu S, Yin H, Li X, Li X, Fan C, Chen G, Feng M, Chen Y. 2021. Short-Term Thinning Influences the Rhizosphere Fungal Community Assembly of Pinus massoniana by Altering the Understory Vegetation Diversity. Frontiers in Microbiology 12:1-14. DOI: 10.3389/fmicb.2021.620309.

Luo W, Zuo X, Ma W, Xu C, Li A, Yu Q, Knapp AK, Tognetti R, Dijkstra FA, Li M. 2018. Differential responses of canopy nutrients to experimental drought along a natural aridity gradient. Ecology 99:2230-2239. DOI: 10.1002/ecy.2444.

Ma Z, Hartmann H, Wang H, Li Q, Wang Y, Li S. 2014. Carbon dynamics and stability between native Masson pine and exotic slash pine plantations in subtropical China. European Journal of Forest Research 133:307-321. DOI: 10.1007/s10342-013-0763-5. Marialigeti S, Tinya F, Bidlo A, Odor P. 2016. Environmental drivers of the composition and diversity of the herb layer in mixed temperate forests in Hungary. Plant Ecology 217:549-563. DOI: 10.1007/s11258-016-0599-4.

Mariotte P, Cresswell T, Johansen MP, Harrison JJ, Keitel C, Dijkstra FA. 2020. Plant uptake of nitrogen and phosphorus among grassland species affected by drought along a soil available phosphorus gradient. Plant and Soil 448:121-132. DOI: 10.1007/s11104-01904407-0.

Miller GW. 2000. Effect of crown growing space on the development of young hardwood crop trees. Northern Journal of Applied Forestry 17:25-35. DOI: 10.1093/njaf/17.1.25. Paillet Y, Berges L, Hjalten J, Odor P, Avon C, Bernhardtromermann M, Bijlsma RJ, De Bruyn L, Fuhr M, Grandin U. 2010. Biodiversity Differences between Managed and Unmanaged Forests: Meta-Analysis of Species Richness in Europe. Conservation Biology 24:101-112. DOI: 10.1111/j.1523-1739.2009.01399.x.

Pan P, Zhao F, Ning J, Zhang L, Ouyang X, Zang H. 2018. Impact of understory vegetation on soil carbon and nitrogen dynamic in aerially seeded Pinus massoniana plantations. PLOS ONE 13. DOI: 10.1371/journal.pone.0191952.

Payn TW, Carnus J, Freersmith PH, Kimberley MO, Kollert W, Liu S, Orazio C, Rodriguez LCE, Silva LN, Wingfield MJ. 2015. Changes in planted forests and future global implications. Forest Ecology and Management 352:57-67. DOI:

10.1016/j.foreco.2015.06.021.

Peer] reviewing PDF | (2021:03:58821:1:0:NEW 3 Jun 2021) 
549

550

551

552

553

554

555

556

557

558

559

560

561

562

563

564

565

566

567

568

569

570

571

572

573

574

575

576

577

578

579

580

581

582

583

584

585

586

587

Perezramos IM, Zavala MA, Maranon T, Diazvilla MD, Valladares F. 2008. Dynamics of understorey herbaceous plant diversity following shrub clearing of cork oak forests: A fiveyear study. Forest Ecology and Management 255:3242-3253. DOI:

10.1016/j.foreco.2008.01.069.

Ray D, Yanai RD, Nyland RD, Mcconnell TR. 2011. Growing-Space Relationships in Young Even-Aged Northern Hardwood Stands Based on Individual-Tree and Plot-Level Measurements. Northern Journal of Applied Forestry 28:27-35. DOI: 10.1093/njaf/28.1.27. Rich CI. 1958. Soil Chemical Analysis. Soil Science Society of America Journal 22:272. DOI: 10.2136/sssaj1958.03615995002200030025x.

Romeo F, Settineri G, Sidari M, Mallamaci C, Muscolo A. 2020. Responses of soil quality indicators to innovative and traditional thinning in a beech (Fagus sylvatica L.) forest. Forest Ecology and Management 465:118106. DOI: 10.1016/j.foreco.2020.118106.

Sanaei A, Yuan Z, Ali A, Loreau M, Mori AS, Reich PB, Jucker T, Lin F, Ye J, Fang S, Hao Z, Wang X. 2021. Tree species diversity enhances plant-soil interactions in a temperate forest in northeast China. Forest Ecology and Management 491. DOI: 10.1016/j.foreco.2021.119160.

Schulze ED, Aas G, Grimm GW, Gossner MM, Walentowski H, Ammer C, Kuhn I, Bouriaud O, Von Gadow K. 2016. A review on plant diversity and forest management of European beech forests. European Journal of Forest Research 135:51-67. DOI: 10.1007/s10342-015-0922-y.

Shen W, Li M, Huang C, He T, Tao X, Wei A. 2019. Local land surface temperature change induced by afforestation based on satellite observations in Guangdong plantation forests in China. Agricultural and Forest Meteorology:107641. DOI:

10.1016/j.agrformet.2019.107641.

Su X, Li S, Wan X, Huang Z, Liu B, Fu S, Kumar P, Chen HYH. 2021. Understory vegetation dynamics of Chinese fir plantations and natural secondary forests in subtropical China. Forest Ecology and Management 483:118750. DOI: 10.1016/j.foreco.2020.118750. Teramage MT, Onda Y, Kato H, Sun X. 2020. Impact of forest thinning on the dynamics of litterfall derived 137Cs deposits in coniferous forest floor after Fukushima accident. Chemosphere 239:124777. DOI: 10.1016/j.chemosphere.2019.124777.

Tonkin JD, Arimoro FO, Haase P. 2016. Exploring stream communities in a tropical biodiversity hotspot: biodiversity, regional occupancy, niche characteristics and environmental correlates. Biodiversity and Conservation 25:975-993. DOI: 10.1007/s10531-016-1101-2.

Wang J, Zhao W, Zhang X, Liu Y, Wang S, Liu Y. 2019. Effects of reforestation on plant species diversity on the Loess Plateau of China: A case study in Danangou catchment. Science of The Total Environment 651:979-989. DOI: 10.1016/j.scitotenv.2018.09.266. Wang F, Zhu W, Zou B, Neher DA, Fu S, Xia H, Li Z. 2013. Seedling growth and soil nutrient availability in exotic and native tree species: implications for afforestation in

Peer) reviewing PDF | (2021:03:58821:1:0:NEW 3 Jun 2021) 
588

589

590

591

592

593

594

595

596

597

598

599

600

601

602

603

604

605

606

607

608

609

610

611

612

613

614

615

616

617

618

619

620

621

622

southern China. Plant and Soil 364:207-218. DOI: 10.1007/s11104-012-1353-x.

Ward JS. 2017. Twenty-five year response of non-crop trees to partial release during precommercial crop tree management. Forest Ecology and Management 387:12-18. DOI: 10.1016/j.foreco.2016.05.036.

Yadav AN, Verma P, Kumar M, Pal KK, Dey R, Gupta A, Padaria JC, Gujar GT, Kumar S, Suman A. 2015. Diversity and phylogenetic profiling of niche-specific Bacilli from extreme environments of India. Annals of Microbiology 65:611-629. DOI: 10.1007/s13213-0140897-9.

Yang X, Li S, Shen B, Wu Y, Sun S, Liu R, Zha R, Li S. 2018. Demographic strategies of a dominant tree species in response to logging in a degraded subtropical forest in Southeast China. Annals of Forest Science 75:84. DOI: 10.1007/s13595-018-0764-0.

Yang L, Maron JL, Callaway RM. 2015. Inhibitory effects of soil biota are ameliorated by high plant diversity. Oecologia 179:519-525. DOI: 10.1007/s00442-015-3351-1.

Yang Q, Zheng F, Jia X, Liu P, Dong S, Zhang J, Zhao B. 2020. The combined application of organic and inorganic fertilizers increases soil organic matter and improves soil microenvironment in wheat-maize field. Journal of Soils and Sediments 20:2395-2404. DOI: $10.1007 /$ s1 1368-020-02606-2.

Yao X, Yu K, Wang G, Deng Y, Lai Z, Chen Y, Jiang Y, Liu J. 2019. Effects of soil erosion and reforestation on soil respiration, organic carbon and nitrogen stocks in an eroded area of Southern China. Science of The Total Environment 683:98-108. DOI: 10.1016/j.scitotenv.2019.05.221.

Yilmaz OY, Yilmaz H, Akyuz YF. 2018. Effects of the overstory on the diversity of the herb and shrub layers of Anatolian black pine forests. European Journal of Forest Research 137:433-445. DOI: 10.1007/s10342-018-1114-3.

Yu K, Yao X, Deng Y, Lai Z, Lin L, Liu J. 2019. Effects of stand age on soil respiration in Pinus massoniana plantations in the hilly red soil region of Southern China. Catena 178:313-321. DOI: 10.1016/j.catena.2019.03.038.

Zhou L, Cai L, He Z, Wang R, Wu P, Ma X. 2016. Thinning increases understory diversity and biomass, and improves soil properties without decreasing growth of Chinese fir in southern China. Environmental Science and Pollution Research 23:24135-24150. DOI: 10.1007/s11356-016-7624-y. Zhou X, Zhu H, Wen Y, Goodale UM, Li X, You Y, Ye D, Liang H. 2017. Effects of understory management on trade-offs and synergies between biomass carbon stock, plant diversity and timber production in eucalyptus plantations. Forest Ecology and Management 410:164-173. DOI: 10.1016/j.foreco.2017.11.015.

Peer) reviewing PDF | (2021:03:58821:1:0:NEW 3 Jun 2021) 
Figure 1

Location of the study area.
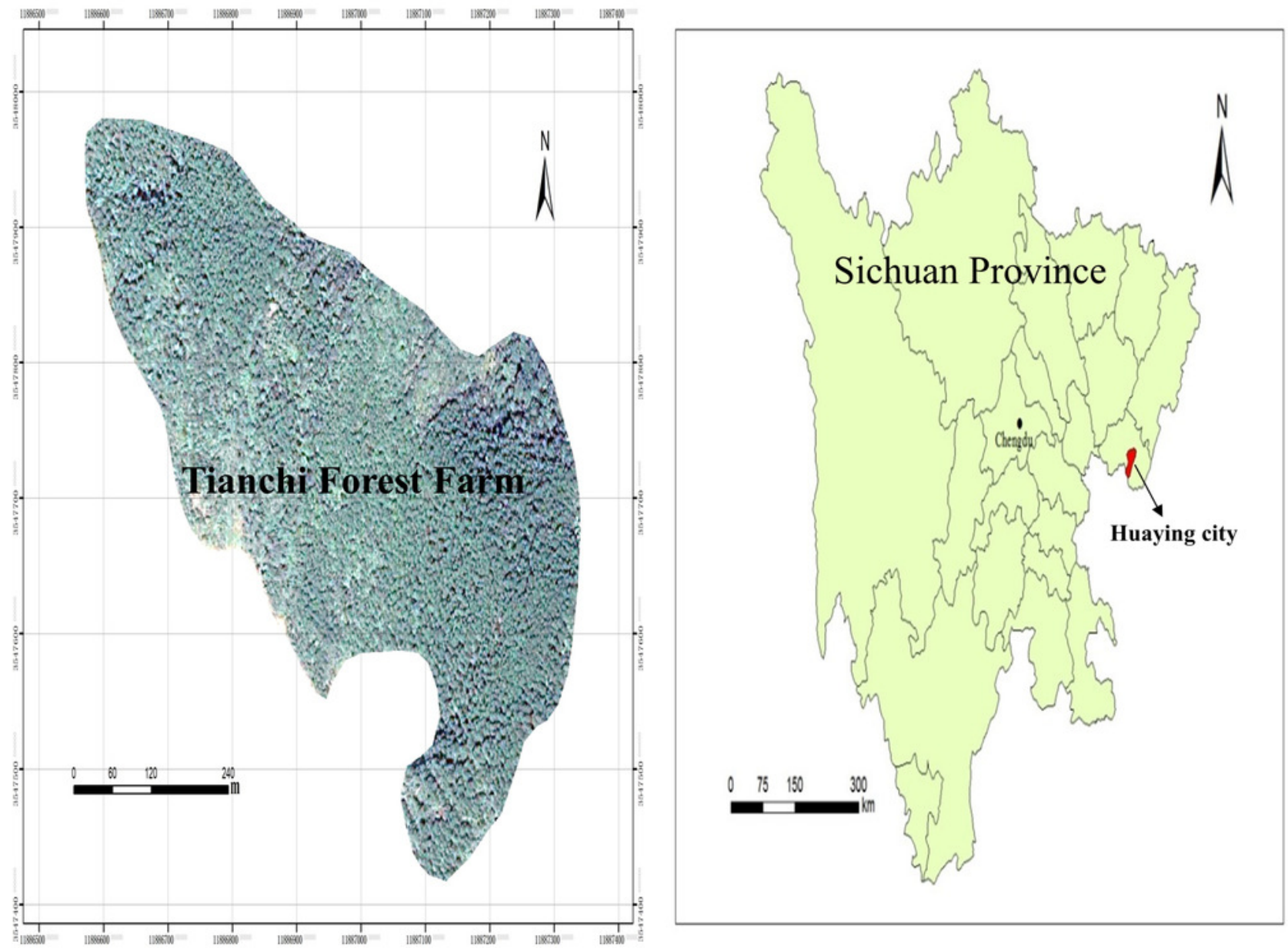
Figure 2

Samplings plots with a crop tree density of $150 \mathrm{~N} / \mathrm{ha}$.

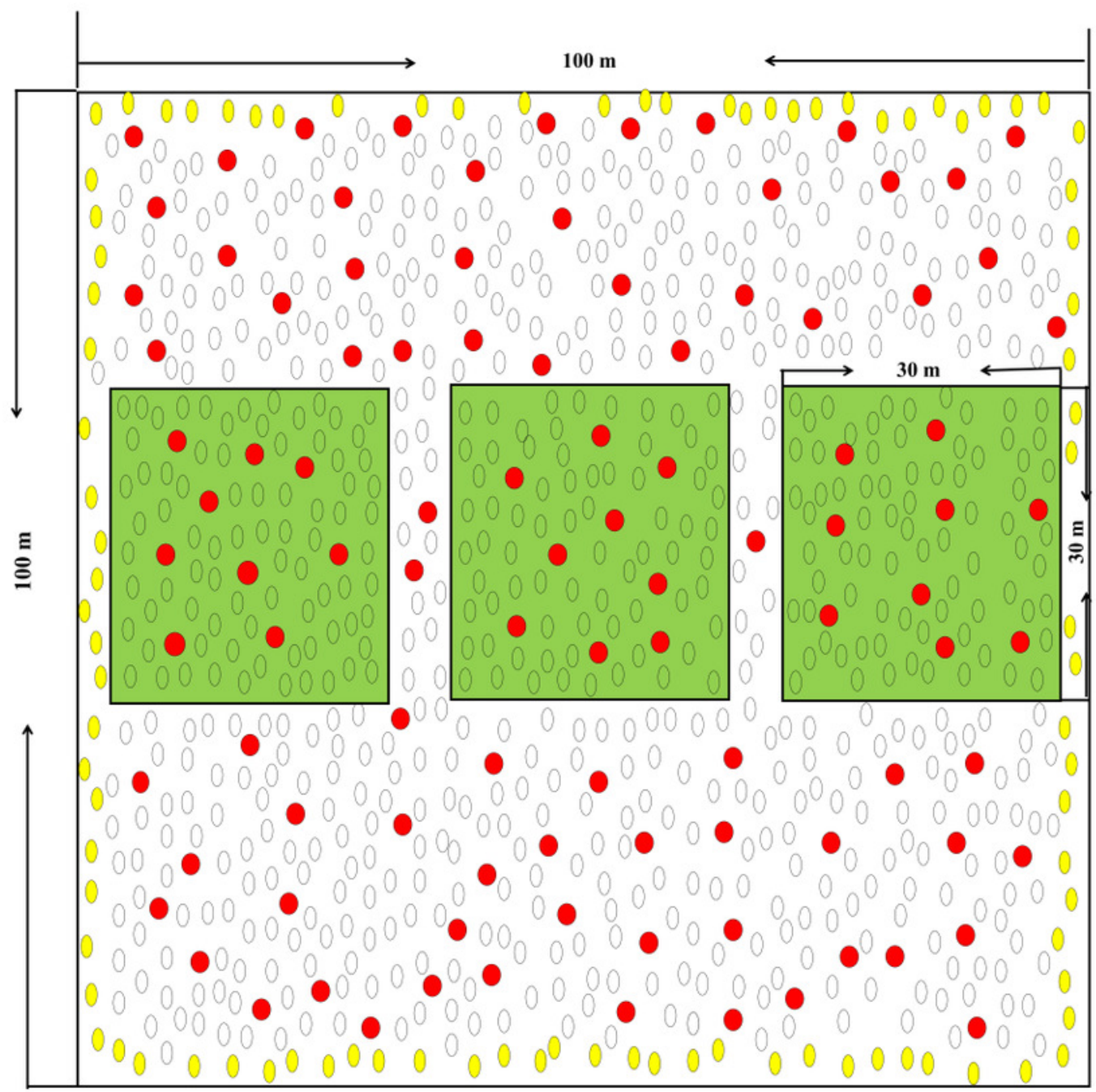

Tree types

Non crop trees

Border trees

Crop trees 
Figure 3

Plant diversity under different treatments.

A (crop tree densities of $100 \mathrm{~N} / \mathrm{ha}$ ), B (crop tree densities of $150 \mathrm{~N} / \mathrm{ha}$ ), C (crop tree densities of $200 \mathrm{~N} / \mathrm{ha}$ ). Different capital letters indicate significant differences among treatments in the shrub layer at $p<0.05$. Different lowercase letters indicate significant differences among treatments in the herb layer at $p<0.05$.

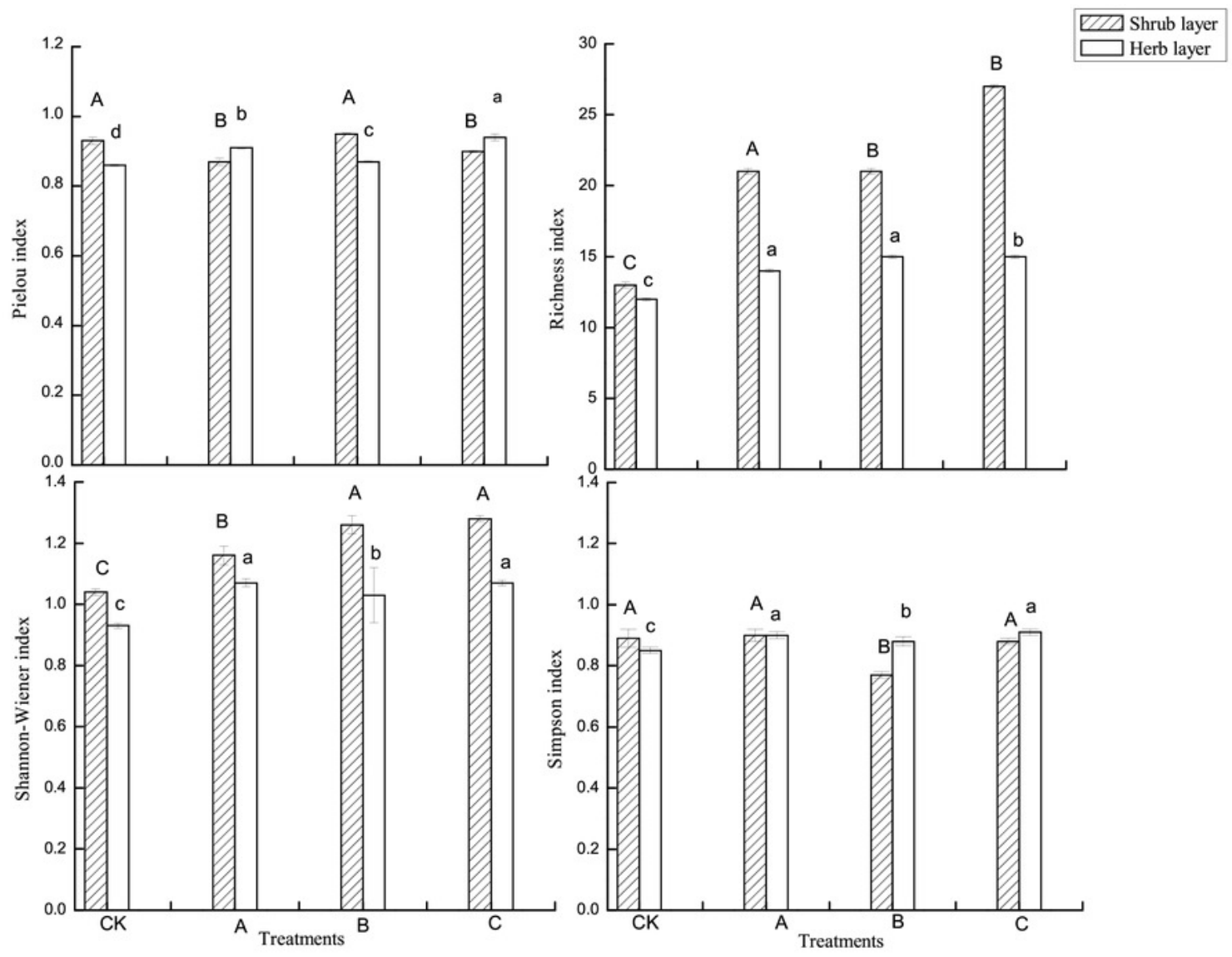




\section{Figure 4}

Correlation coefficient of plant diversity and soil physical and chemical properties under different crop tree management.

R1: The richness index of the shrub layer, R2: The richness index of the herb layer, H1: The Shannon-Wiener index of the shrub layer, H2: The Shannon-Wiener index of the herb layer, D1: The simpson index of the shrub layer, D2: The Simpson index of the herb layer, J1: The Pielou index of the shrub layer, J2: The Pielou index of the herb layer $\left(* P<0.05,{ }^{* *} P<\right.$ $0.01)$.

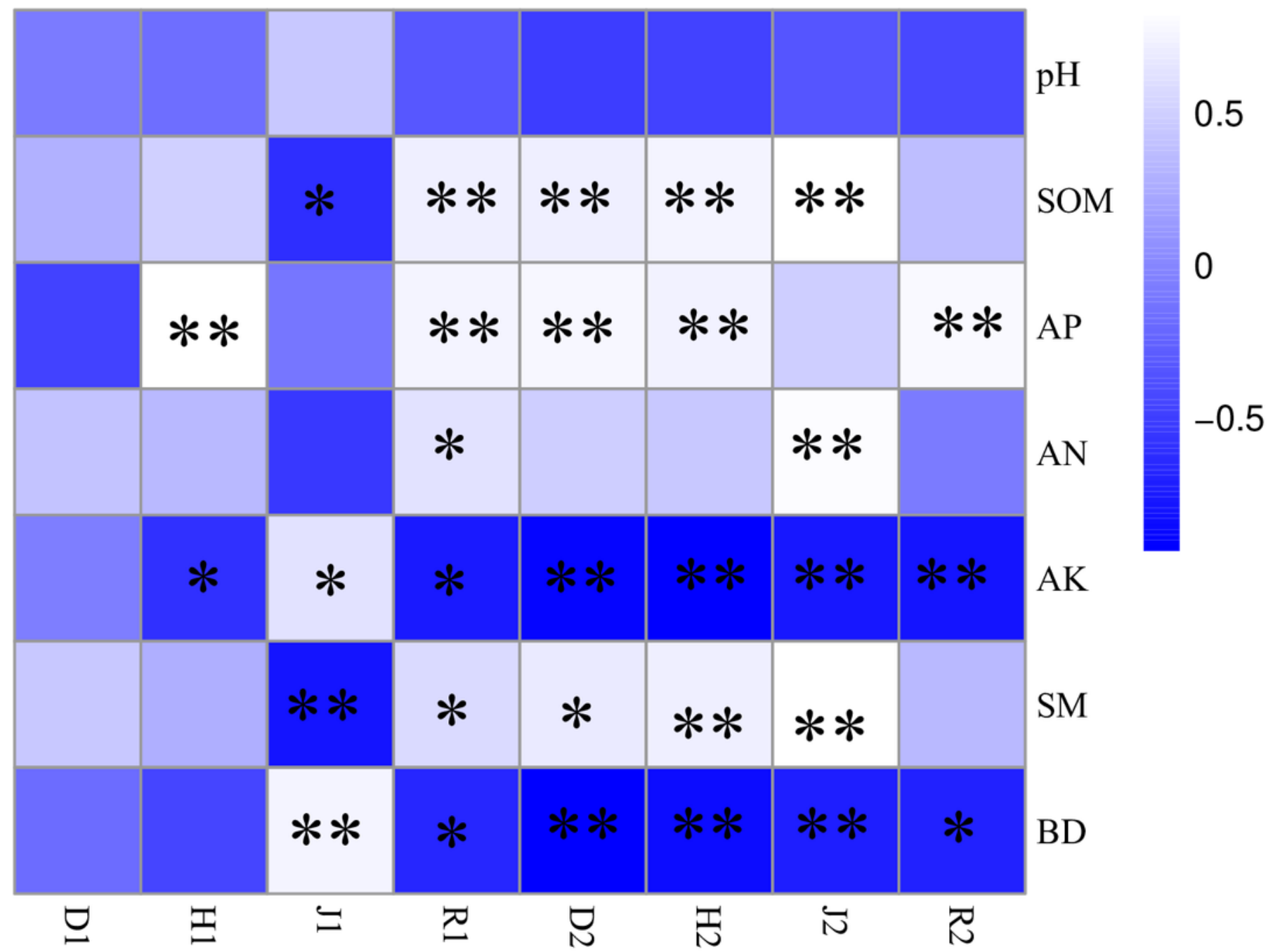




\section{Figure 5}

RDA analysis plot showing the relationships between soil physicochemical properties and shrub and herb composition at soil depth layers of 0-10 and 10-20 cm, respectively.

(A) The shurb layer at $0-10 \mathrm{~cm}$ soil layer. (B) The shurb layer at $10-20 \mathrm{~cm}$ soil layer. (C) The herb layer at $0-10 \mathrm{~cm}$ soil layer. (D) The herb layer at $10-20 \mathrm{~cm}$ soil layer. The numerical serial number represents different kinds of plants. Refer to Tables 2 and 3 for the specific meaning.The figures show only the top ten plants in terms of relative abundance.
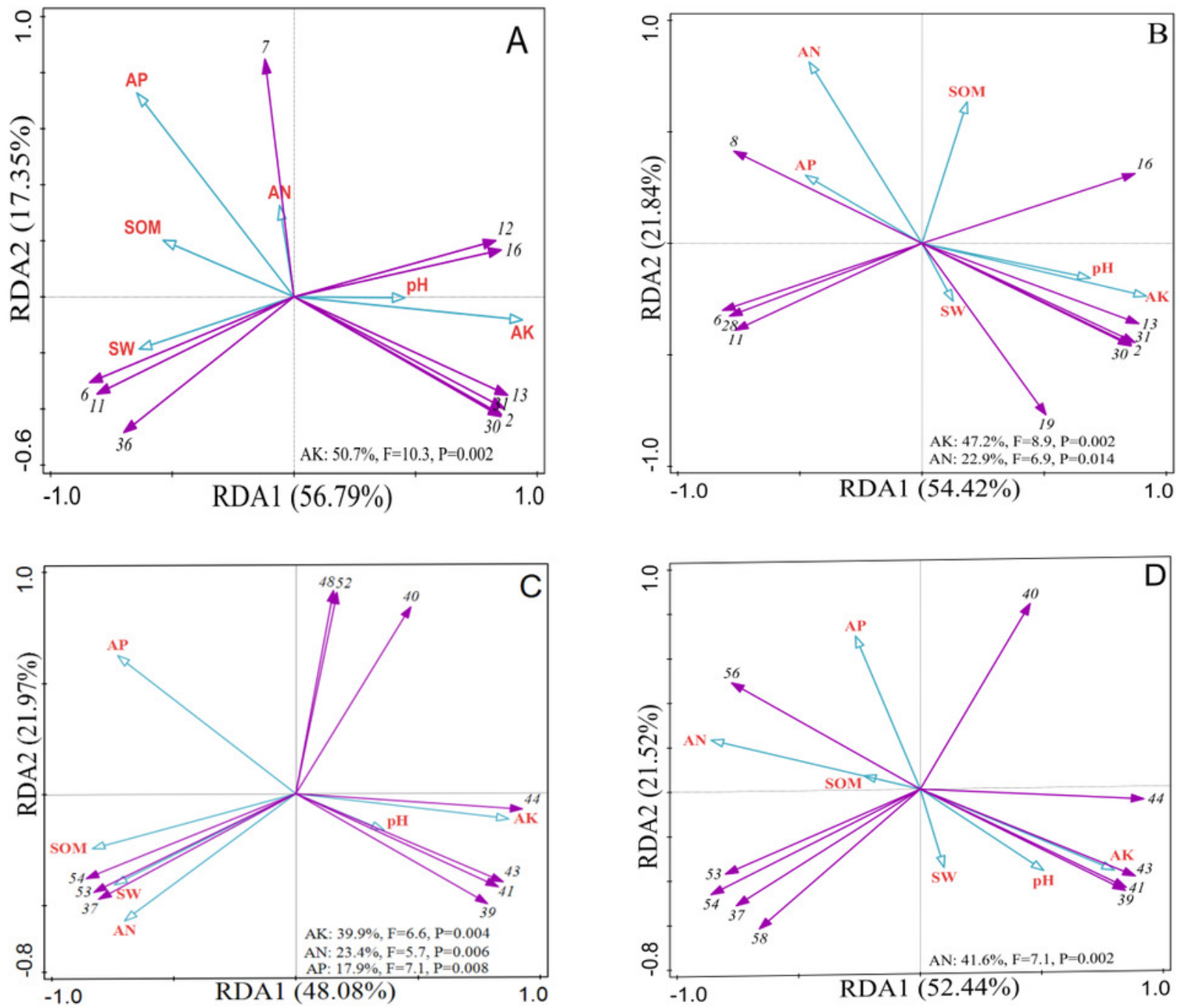
Figure 6

Principal component analyses of crop tree management of $P$. massoniana plantation.

A (crop tree densities of $100 \mathrm{~N} / \mathrm{ha}$ ), B (crop tree densities of $150 \mathrm{~N} / \mathrm{ha}$ ), C (crop tree densities of $200 \mathrm{~N} / \mathrm{ha}$ ).

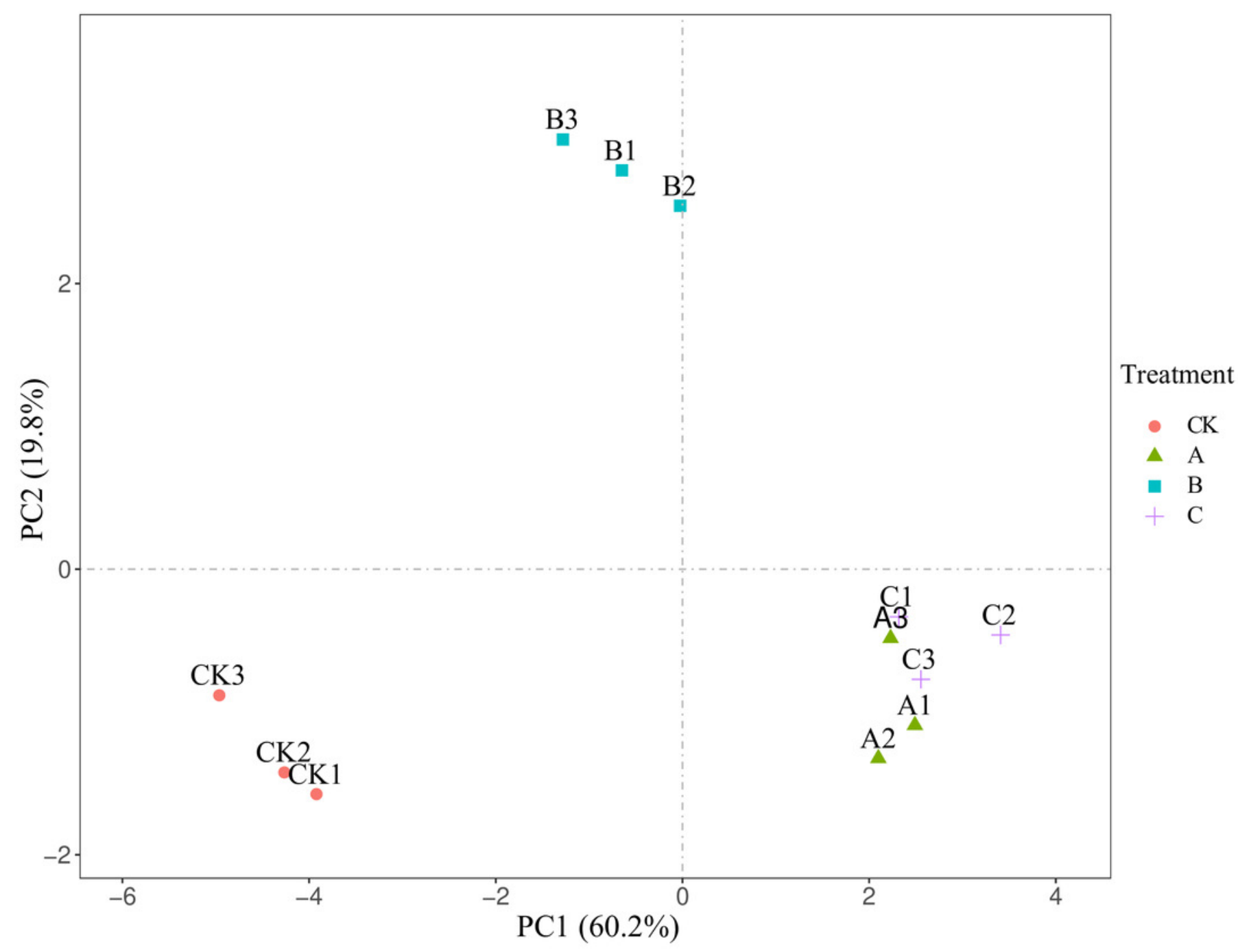




\section{Table $\mathbf{1}$ (on next page)}

Growth of Pinus massoniana before and after crop tree management.

A (crop tree densities of $100 \mathrm{~N} / \mathrm{ha}$ ), B (crop tree densities of $150 \mathrm{~N} / \mathrm{ha}$ ), C (crop tree densities of $200 \mathrm{~N} / \mathrm{ha}$ ). 
1

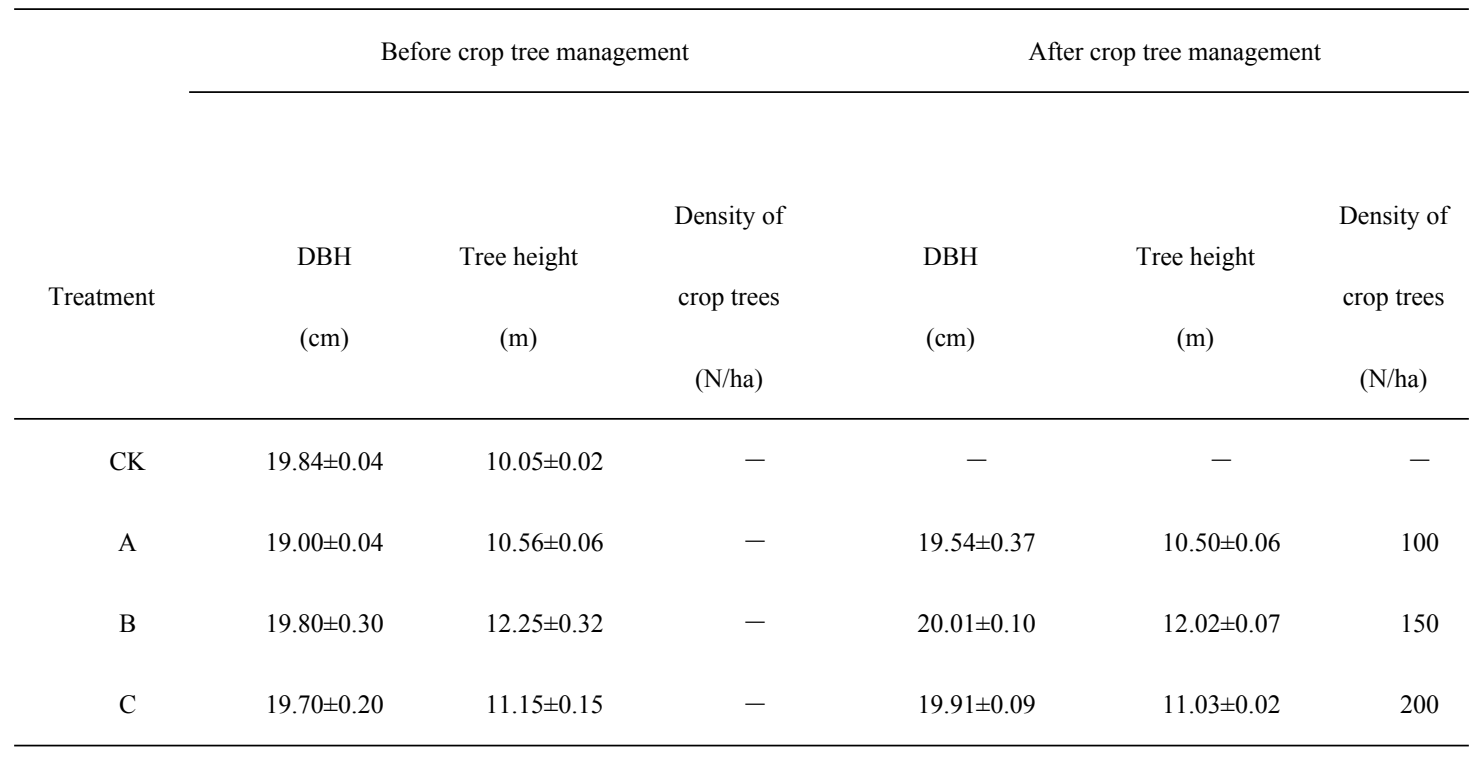

2 


\section{Table 2 (on next page)}

The importance value (IV/\%) and niche breadth (Bi) of the shrub layer in a $P$. massoniana plantation in the early stage of crop tree management.

A (crop tree densities of $100 \mathrm{~N} / \mathrm{ha}$ ), B (crop tree densities of $150 \mathrm{~N} / \mathrm{ha}$ ), C (crop tree densities of $200 \mathrm{~N} / \mathrm{ha}$ ) 
1

\begin{tabular}{|c|c|c|c|c|c|c|c|c|c|}
\hline \multirow{3}{*}{$\begin{array}{c}\text { Serial } \\
\text { number }\end{array}$} & \multirow{3}{*}{ Species } & \multicolumn{8}{|c|}{ Treatment } \\
\hline & & \multicolumn{2}{|c|}{$\mathrm{CK}$} & \multicolumn{2}{|c|}{$\mathrm{A}$} & \multicolumn{2}{|c|}{$\mathrm{B}$} & \multicolumn{2}{|c|}{$\mathrm{C}$} \\
\hline & & IV & $\mathrm{Bi}$ & IV & $\mathrm{Bi}$ & IV & $\mathrm{Bi}$ & IV & $\mathrm{Bi}$ \\
\hline 1 & Myrsine africana & - & - & 3.13 & 1.4 & 5.42 & 1.44 & 3.45 & 1.43 \\
\hline 2 & Cinnamomum camphora & 18.25 & 1.38 & 8.51 & 1.36 & 4.98 & 1.09 & 4.42 & 1.03 \\
\hline 3 & Rubus pirifolius & 3.92 & 1.43 & - & - & 4 & 1.43 & 6.06 & 1.45 \\
\hline 4 & Mallotus barbatus & 16.07 & 1.36 & 8.09 & 1 & 23.03 & 1.46 & 22.13 & 1.46 \\
\hline 5 & Aralia chinensis & - & - & - & - & 1.04 & 1.16 & 1.78 & 3.72 \\
\hline 6 & Eurya brevistyla & 4.17 & 1.29 & 8.59 & 1.46 & 5.11 & 1.38 & 3.01 & 1.12 \\
\hline 7 & Smilax china & - & - & - & - & 2.9 & 1.29 & 2.24 & 1.45 \\
\hline 8 & Litsea pungens & 11.96 & 1.28 & 17.52 & 1.44 & 16.21 & 1.41 & 14.64 & 1.37 \\
\hline 9 & Callicarpa giraldii & - & - & 3.65 & 0.71 & - & - & 0.91 & 1.29 \\
\hline 10 & Melastoma malabathricum & 5.08 & 1.41 & 3.35 & 1.23 & 4.31 & 1.35 & 6.07 & 1.46 \\
\hline 11 & Ardisia japonica & - & - & 4.78 & 1.38 & 2.34 & 1.38 & 2.41 & 1.39 \\
\hline 12 & Quercus serrata & 10.41 & 1.47 & 5.57 & 1.28 & 6.3 & 1.34 & 5.73 & 1.3 \\
\hline 13 & Serissa japonica & 4.1 & 0.93 & - & - & - & - & 1.54 & 1.42 \\
\hline 14 & Rubus buergeri & - & - & - & - & - & - & 1.89 & 0 \\
\hline 15 & Smilax discotis & - & - & - & - & 2.94 & 1.25 & 2.05 & 1.46 \\
\hline 16 & Gardenia jasminoides & 2.98 & 1.4 & 3.23 & 1.43 & 1.84 & 1.17 & 3.48 & 1.45 \\
\hline 17 & Ficus pandurata & 3.95 & 1.34 & 5.78 & 1.46 & 4.58 & 1.4 & 3.53 & 1.28 \\
\hline 18 & Pithecellobium lucidum & - & - & - & - & - & - & 0.97 & 0 \\
\hline 19 & Urena lobata & 7.82 & 1.27 & 3.61 & 1.41 & 1.34 & 0.91 & 0.84 & 0.69 \\
\hline 20 & Smilax arisanensis & - & - & - & - & 2.13 & 1.31 & 1.71 & 1.44 \\
\hline 21 & Callicarpa bodinieri & - & - & - & - & - & - & 0.82 & 0 \\
\hline 22 & Rhododendron simsii & - & - & 3.1 & 1.17 & - & - & 1.85 & 1.47 \\
\hline 23 & Rubus corchorifolius & - & - & 4.12 & 1.3 & 1.59 & 1.32 & 1.66 & 1.34 \\
\hline 24 & Lonicera japonica & - & - & - & - & - & - & 1.08 & 0 \\
\hline 25 & Mallotus philippensis & - & - & - & - & - & - & 0.78 & 0 \\
\hline 26 & Ardisia crispa & - & - & - & - & - & - & 1.62 & 0 \\
\hline 27 & Pericampylus glaucus & - & - & 4.88 & 1.47 & 4.13 & 1.47 & 3.34 & 1.41 \\
\hline 28 & Ampelopsis delavayana & - & - & 3.07 & 0.87 & 1.03 & 1.39 & - & - \\
\hline 29 & Millettia congestiflora & - & - & 4 & 1.37 & 2.88 & 1.47 & - & - \\
\hline 30 & Debregeasia orientalis & 9.01 & 0 & - & - & - & - & - & - \\
\hline 31 & Rhus chinensis & 2.28 & 0 & - & - & - & - & - & - \\
\hline 32 & Symplocos lancifolia & - & - & 3.41 & 0 & - & - & - & - \\
\hline 33 & Broussonetia kaempferi & - & - & 4.01 & 0 & - & - & - & - \\
\hline 34 & Lespedeza bicolor & - & - & - & - & 1.88 & 0 & - & - \\
\hline 35 & Dalbergia hupeana & - & - & 6.26 & 0 & & & - & - \\
\hline 36 & Ficus henryi & - & - & 3.17 & 0 & - & - & - & - \\
\hline
\end{tabular}




\section{Table 3 (on next page)}

The importance value (IV/\%) and niche breadth (Bi) of the herb layer in the early stage of crop tree management in a Pinus massoniana plantation.

A (crop tree densities of $100 \mathrm{~N} / \mathrm{ha}$ ), B (crop tree densities of $150 \mathrm{~N} / \mathrm{ha}$ ), C (crop tree densities of $200 \mathrm{~N} / \mathrm{ha}$ ). 
1

\begin{tabular}{|c|c|c|c|c|c|c|c|c|c|}
\hline \multirow{3}{*}{ Serial number } & \multirow{3}{*}{ Species } & \multicolumn{8}{|c|}{ Treatment } \\
\hline & & \multicolumn{2}{|c|}{$\mathrm{CK}$} & \multicolumn{2}{|c|}{ A } & \multicolumn{2}{|c|}{$\mathrm{B}$} & \multicolumn{2}{|c|}{$\mathrm{C}$} \\
\hline & & IV & $\mathrm{Bi}$ & IV & $\mathrm{Bi}$ & IV & $\mathrm{Bi}$ & IV & $\mathrm{Bi}$ \\
\hline 37 & Lophatherum gracile & 2.85 & 1.17 & 6.24 & 1.47 & 2.28 & 1.05 & 6.47 & 1.47 \\
\hline 38 & Woodwardia japonica & 4.83 & 1.30 & - & - & 9.42 & 1.47 & 9.43 & 1.47 \\
\hline 39 & $\begin{array}{l}\text { Dendranthema } \\
\text { indicum }\end{array}$ & 3.78 & 0.88 & 1.31 & 1.40 & - & - & - & - \\
\hline 40 & Dryopteris fuscipes & 11.79 & 1.39 & 8.90 & 1.27 & 22.06 & 1.41 & 3.35 & 0.76 \\
\hline 41 & $\begin{array}{c}\text { Parathelypteris } \\
\text { glanduligera }\end{array}$ & 6.62 & 0.00 & - & - & - & - & - & - \\
\hline 42 & Erigeron annuus & 1.56 & 1.44 & - & - & - & - & 3.82 & 0.97 \\
\hline 43 & Setaria plicata & 28.53 & 1.42 & 13.81 & 1.35 & 10.52 & 1.22 & 7.56 & 1.04 \\
\hline 44 & Oxalis corniculata & 6.62 & 0.94 & - & - & 2.57 & 1.42 & - & - \\
\hline 45 & $\begin{array}{c}\text { Sanguisorba } \\
\text { officinalis }\end{array}$ & - & - & 1.31 & 0.00 & - & - & - & - \\
\hline 46 & Cyrtomium fortunei & - & - & 2.61 & 0.00 & - & - & - & - \\
\hline 47 & Lygodium japonicum & - & - & 2.85 & 1.17 & 1.71 & 1.47 & - & - \\
\hline 48 & $\begin{array}{c}\text { Capillipedium } \\
\text { parviflorum }\end{array}$ & - & - & - & - & 2.50 & 0.00 & - & - \\
\hline 49 & $\begin{array}{c}\text { Dicranopteris } \\
\text { dichotoma }\end{array}$ & - & - & 11.19 & 1.45 & 4.36 & 1.17 & 11.15 & 1.46 \\
\hline 50 & Blumea megacephala & - & - & - & - & - & - & 7.09 & 0.00 \\
\hline 51 & Alpinia japonica & - & - & - & - & - & - & 1.64 & 0.00 \\
\hline 52 & $\begin{array}{l}\text { Oplismenus } \\
\text { compositus }\end{array}$ & - & - & - & - & - & - & 3.57 & 0.00 \\
\hline 53 & Liriope spicata & - & - & 2.91 & 1.46 & - & - & 4.13 & 1.25 \\
\hline 54 & Stenoloma chusanum & - & - & 6.00 & 1.46 & - & - & 12.86 & 1.04 \\
\hline
\end{tabular}




\begin{tabular}{cccccccccccc}
55 & Dioscorea opposita & - & - & - & - & 1.75 & 0.00 & - & - \\
& & & & & & & & \\
56 & Microlepia hancei & - & - & 6.58 & 1.31 & 12.70 & 1.46 & 12.17 & 1.47 \\
& & & & & & & & & \\
57 & Arthraxon hispidus & 3.98 & 1.32 & 9.91 & 1.34 & 2.28 & 1.03 & 2.33 & 1.04 \\
58 & Pteridium aquilinum & 4.20 & 1.28 & 7.12 & 1.47 & 2.28 & 0.96 & 7.56 & 1.47 \\
59 & Miscanthus sinensis & 13.02 & 1.44 & 6.88 & 1.15 & 14.20 & 1.46 & 10.44 & 1.36 \\
60 & Iris tectorum & 12.23 & 1.47 & 11.59 & 1.47 & 7.81 & 1.38 & - & - \\
\hline
\end{tabular}

2 


\section{Table 4 (on next page)}

Soil physicochemical properties under different soil layers in the early stage of crop tree management.

A (crop tree densities of $100 \mathrm{~N} / \mathrm{ha}$ ), B (crop tree densities of $150 \mathrm{~N} / \mathrm{ha}$ ), C (crop tree densities of $200 \mathrm{~N} / \mathrm{ha}$ ). Different small letters indicate significant differences among treatments in $p<$ 0.05 . 


\begin{tabular}{|c|c|c|c|c|c|c|c|c|}
\hline Soil layers & Treatment & $\mathrm{pH}$ & $\begin{array}{c}\mathrm{SOM} \\
(\mathrm{mg} / \mathrm{kg})\end{array}$ & $\begin{array}{c}\mathrm{AP} \\
(\mathrm{mg} / \mathrm{kg})\end{array}$ & $\begin{array}{c}\mathrm{AN} \\
(\mathrm{mg} / \mathrm{kg})\end{array}$ & $\begin{array}{c}\mathrm{AK} \\
(\mathrm{mg} / \mathrm{kg})\end{array}$ & $\begin{array}{l}\text { SM } \\
(\%)\end{array}$ & $\begin{array}{c}\mathrm{BD} \\
\left(\mathrm{g} / \mathrm{cm}^{3}\right)\end{array}$ \\
\hline \multirow{4}{*}{$0-10 \mathrm{~cm}$} & $\mathrm{CK}$ & $3.67 \pm 0.04 \mathrm{a}$ & $18.86 \pm 9.55 \mathrm{c}$ & $1.32 \pm 0.29 b$ & $271.21 \pm 52.36 \mathrm{bc}$ & $80.58 \pm 1.48 \mathrm{a}$ & $23.80 \pm 0.74 \mathrm{~b}$ & $1.40 \pm 0.01 \mathrm{a}$ \\
\hline & A & $3.43 \pm 0.12 \mathrm{a}$ & $34.88 \pm 1.88 \mathrm{ab}$ & $4.65 \pm 0.93 \mathrm{a}$ & $314.58 \pm 23.07 \mathrm{~b}$ & $64.56 \pm 0.96 \mathrm{~d}$ & $27.19 \pm 1.33 \mathrm{a}$ & $1.38 \pm 0.02 \mathrm{~b}$ \\
\hline & B & $3.46 \pm 0.15 \mathrm{a}$ & $22.91 \pm 5.09 \mathrm{bc}$ & $5.95 \pm 1.28 \mathrm{a}$ & $208.00 \pm 81.27 \mathrm{c}$ & $72.32 \pm 1.89 \mathrm{~b}$ & $23.73 \pm 0.77 b$ & $1.36 \pm 0.03 b$ \\
\hline & $\mathrm{C}$ & $3.50 \pm 0.14 \mathrm{a}$ & $39.03 \pm 6.66 \mathrm{c}$ & $5.37 \pm 1.59 \mathrm{a}$ & $481.60 \pm 0.21 \mathrm{a}$ & $68.36 \pm 2.57 \mathrm{c}$ & $26.67 \pm 0.25 \mathrm{a}$ & $1.33 \pm 0.01 \mathrm{~b}$ \\
\hline \multirow{4}{*}{$10-20 \mathrm{~cm}$} & $\mathrm{CK}$ & $3.67 \pm 0.04 \mathrm{a}$ & $24.69 \pm 1.28 \mathrm{a}$ & $2.75 \pm 3.10 \mathrm{~b}$ & $247.79 \pm 41.38 \mathrm{c}$ & $76.74 \pm 3.02 \mathrm{a}$ & $24.41 \pm 3.27 \mathrm{a}$ & $1.41 \pm 0.03 \mathrm{a}$ \\
\hline & A & $3.43 \pm 0.12 \mathrm{a}$ & $19.40 \pm 3.96 \mathrm{a}$ & $4.95 \pm 1.43 \mathrm{ab}$ & $321.03 \pm 34.87 \mathrm{~b}$ & $59.11 \pm 0.63 b$ & $24.11 \pm 0.60 \mathrm{a}$ & $1.40 \pm 0.02 \mathrm{a}$ \\
\hline & B & $3.46 \pm 0.15 \mathrm{a}$ & $29.32 \pm 11.97 \mathrm{a}$ & $6.70 \pm 0.42 \mathrm{a}$ & $351.37 \pm 36.24 \mathrm{ab}$ & $63.08 \pm 5.56 \mathrm{~b}$ & $23.05 \pm 0.67 \mathrm{a}$ & $1.41 \pm 0.02 \mathrm{a}$ \\
\hline & $\mathrm{C}$ & $3.47 \pm 0.14 \mathrm{a}$ & $32.46 \pm 12.80 \mathrm{a}$ & $4.31 \pm 0.89 \mathrm{ab}$ & $401.24 \pm 0.33 \mathrm{a}$ & $61.84 \pm 1.00 \mathrm{~b}$ & $23.97 \pm 0.19 \mathrm{a}$ & $1.41 \pm 0.01 \mathrm{a}$ \\
\hline
\end{tabular}

1 


\section{Table 5 (on next page)}

Results of two-way ANOVA for the effects of crop tree management (CTM), soil layers $(\mathrm{SL})$, and their interactions (CTM $\times \mathrm{SL}$ ) on soil physicochemical properties. (DF: Degrees of freedom).

A (crop tree densities of $100 \mathrm{~N} / \mathrm{ha}$ ), B (crop tree densities of $150 \mathrm{~N} / \mathrm{ha}$ ), C (crop tree densities of $200 \mathrm{~N} / \mathrm{ha}$ ). 
1

\begin{tabular}{|c|c|c|c|c|}
\hline Index & & CTM & $\mathrm{SL}$ & $\mathrm{CTM} \times \mathrm{SL}$ \\
\hline \multirow{3}{*}{$\mathrm{pH}$} & $\mathrm{F}$ & 2.506 & 0.695 & 0.108 \\
\hline & $\mathrm{P}$ & 0.096 & 0.417 & 0.954 \\
\hline & $\mathrm{DF}$ & 3 & 1 & 3 \\
\hline \multirow{3}{*}{ SOM } & $\mathrm{F}$ & 3.356 & 0.589 & 2.726 \\
\hline & $\mathrm{P}$ & 0.045 & 0.454 & 0.079 \\
\hline & DF & 3 & 1 & 3 \\
\hline \multirow{3}{*}{ AP } & $\mathrm{F}$ & 8.682 & 0.341 & 0.748 \\
\hline & $\mathrm{P}$ & 0.001 & 0.568 & 0.539 \\
\hline & DF & 3 & 1 & 3 \\
\hline \multirow{3}{*}{ AN } & $\mathrm{F}$ & 22.604 & 0.450 & 7.669 \\
\hline & $\mathrm{P}$ & $<0.001$ & 0.512 & 0.002 \\
\hline & DF & 3 & 1 & 3 \\
\hline \multirow{3}{*}{$\mathrm{AK}$} & $\mathrm{F}$ & 46.701 & 34.428 & 1.130 \\
\hline & $\mathrm{P}$ & $<0.001$ & $<0.001$ & 0.367 \\
\hline & DF & 3 & 1 & 3 \\
\hline \multirow{3}{*}{$\mathrm{SM}$} & $\mathrm{F}$ & 3.675 & 7.070 & 2.512 \\
\hline & $\mathrm{P}$ & 0.035 & 0.017 & 0.096 \\
\hline & DF & 3 & 1 & 3 \\
\hline \multirow{3}{*}{$\mathrm{BD}$} & $\mathrm{F}$ & 7.879 & 52.364 & 5.576 \\
\hline & $\mathrm{P}$ & 0.002 & $<0.001$ & 0.008 \\
\hline & DF & 3 & 1 & 3 \\
\hline
\end{tabular}

2 
Table 6(on next page)

The eigenvalues and percent of variance explained. 
1

\begin{tabular}{cccc}
\hline Index & Principal component 1 & Principal component 2 & Principal component 3 \\
\hline Eigenvalue & 9.029 & 2.973 & 1.448 \\
Explained/\% & 60.194 & 19.822 & 9.654 \\
Cumulative Variance & 60.194 & 80.016 & 89.67 \\
Explained/\% & & & \\
\hline
\end{tabular}

2

3 


\section{Table 7 (on next page)}

Comprehensive appraisal value and ranking in the early stage of crop tree management.

A (crop tree densities of $100 \mathrm{~N} / \mathrm{ha}$ ), B (crop tree densities of $150 \mathrm{~N} / \mathrm{ha}$ ), C (crop tree densities of $200 \mathrm{~N} / \mathrm{ha}$ ). 
1

\begin{tabular}{|c|c|c|c|c|c|}
\hline \multirow{2}{*}{ Treatments } & \multicolumn{3}{|c|}{ Principal component } & \multirow{2}{*}{$\frac{\text { Comprehensive evaluation }}{\mathrm{F}}$} & \multirow{2}{*}{ Rank } \\
\hline & $\mathrm{F} 1$ & $\mathrm{~F} 2$ & F3 & & \\
\hline $\mathrm{CK}$ & -1.458 & -0.75 & 0.112 & -1.133 & 4 \\
\hline $\mathrm{A}$ & 0.756 & -0.561 & -1.027 & 0.273 & 2 \\
\hline $\mathrm{B}$ & -0.217 & 1.613 & -0.202 & 0.189 & 3 \\
\hline $\mathrm{C}$ & 0.919 & -0.303 & 1.117 & 0.992 & 1 \\
\hline
\end{tabular}

2 